\title{
Risk of lung cancer in Parkinson's disease
}

\author{
Xin $\mathrm{Xie}^{1}$, Xiaoguang Luo ${ }^{1}$, Mingliang $\mathrm{Xie}^{2}$, Yang Liu ${ }^{1}$, Ting $\mathbf{W u}^{1}$ \\ ${ }^{1}$ Department of Neurology, The First Affiliated Hospital of China Medical University, Shenyang City 110001, PR China \\ ${ }^{2}$ Clinics of the People's Armed Police Command College, Tianjin City, 300000, PR China
}

Correspondence to: Xiaoguang Luo, email: grace_shenyang@163.com

Keywords: lung neoplasms, meta-analysis, Parkinson's disease, risk

Received: September 14, $2016 \quad$ Accepted: October 14, 2016

Published: October 27, 2016

\section{ABSTRACT}

Recently, growing evidence has revealed the significant association between Parkinson's disease (PD) and cancer. However, controversy still exists concerning the association between PD and lung cancer. A comprehensive article search for relevant studies published was performed using the following online databases: PubMed, Web of Science and Embase up to August 31, 2016. The pooled risk ratio (RR) and their $95 \%$ confidence intervals (CI) were calculated using the method of inverse variance with the random-effects model. Fifteen studies comprising 348,780 PD patients were included in this study. The pooled result indicated that patients with PD were significantly associated with a decreased risk of lung cancer (RR: 0.53 , 95\% CI: 0.41-0.70, $P<0.001)$. In addition, subgroup analyses performed in Western population also confirmed the significant inverse relationship between PD and risk of lung cancer (RR: $0.48,95 \%$ CI: $0.39-0.60, P<0.001$ ). In the subgroup analysis, a reduced risk of lung cancer in PD patients from Western population was consistent regardless of study design, gender, or study quality. In conclusion, PD patients were significantly associated with a reduced risk of lung cancer in Western population. The relationship between them in Asian population needs to be confirmed by future studies.

\section{INTRODUCTION}

Parkinson's disease (PD) is the second most common neurodegenerative disorders characterized by the selective dopaminergic cell loss in the substantia nigra, and the prevalence of PD of the entire population is about $0.3 \%$ in industrialized countries [1]. Most PD cases are sporadic and until now the exact etiology of PD still remains unknown.

It is all to know that cancer is a disease characterized by cell infinite proliferation and lack of apoptosis. Recently, growing evidence has revealed the significant association between PD and cancer [2, 3], and PD plays different roles in risk of different cancers. For instance, some studies reported that PD was significantly associated with an increased risk of melanoma [4], but with a decreased risk of bladder cancer [5]. However, controversy still exists concerning the association between $\mathrm{PD}$ and lung cancer $[3,6,7]$. On the other hand, there is some potential evidence to link PD with lung cancer. For instance, PD and lung cancer are both regarded as disease characterized by multi-factor disorders involving genomic and environmental factors. Mutation of the PD-associated gene PARK2 also can be observed in lung cancer [8].
Moreover, recent studies reported that smoking played different roles in risk of PD and lung cancer $[9,10]$. Thus, this controversial relationship between PD and lung cancer catches our attention.

In this study, we included the cohort and case-control studies to perform a meta-analysis which aimed to explore the association between PD and risk of lung cancer.

\section{RESULTS}

Baseline characteristics of included studies

A total of 371 potentially relevant studies were identified in the database search. After exclusion of 296 duplicated studies, there were remain 130 studies. After title and abstract review, 97 studies were excluded. After full article review for the remaining 33 studies, 7 duplicated studies which were performed in the same population and 11 studies which did not meet inclusion criteria were excluded (Supplementary material 1). Finally, 15 studies were included in our meta-analysis [5-7, 11-22] (Figure 1).

These studies were published between 2000 and 2016, and contained 348,780 patients with PD. Among these 
15 studies, 2 studies were performed in Asian population ( 1 in Japan and 1 in Taiwan), while 13 studies were conducted in Western population (6 in USA, 3 in UK, 1 in Canada, 1 in Denmark, 1 in Israel and 1 in Sweden). The baseline characteristics of each study are shown in Table 1.

\section{PD and risk of lung cancer}

The result of 12 cohort studies and 3 case-control studies indicated that the pooled RR of lung cancer in PD patients versus control patients was 0.53 (95\% CI: $0.41-0.70, P<0.001, I^{2}=94 \%$, Figure 2), thus showing that PD patients had a reduced risk of lung cancer.

In addition, we excluded two studies which were based on Asian population [7, 11] and performed further analyses in Western population. The pooled result showed that patients with PD were significantly associated with a decreased risk of lung cancer in Western population (RR: 0.48, 95\% CI: 0.39-0.60, $P<0.001, I^{2}=85 \%$, Table 2). Furthermore, subgroup analyses revealed the significance of the inverse association between PD and risk of lung cancer was not affected by many factors such as study design, gender and study quality (Table 2).
On the other hand, according to the diagnosis time of lung cancer, we divide the studies into before PD and after PD these two groups to perform subgroup analysis. The result indicated that the significant inverse relationship between PD and the risk of lung cancer could be found in after PD group (RR: 0.49, 95\% CI: 0.40-0.60, $P<0.001$ ), but it could not be found in before PD group (RR: $0.49,95 \%$ CI: $0.21-1.14, P=0.10$, Table 2).

\section{Sensitivity analysis}

In this study, sensitivity analysis was used to assess the stability of the results. The significant inverse association between PD and risk of lung cancer did not change in the sensitivity analysis, which removed each study in turn (Figure S1).

\section{Publication bias analysis}

In our meta-analysis, we used Begg's and Egger's tests to evaluate the effect of publication bias. The result indicated that there was no evidence of publication bias (Begg, $P=0.151$; Egger, $P=0.214$, Figure 3 )

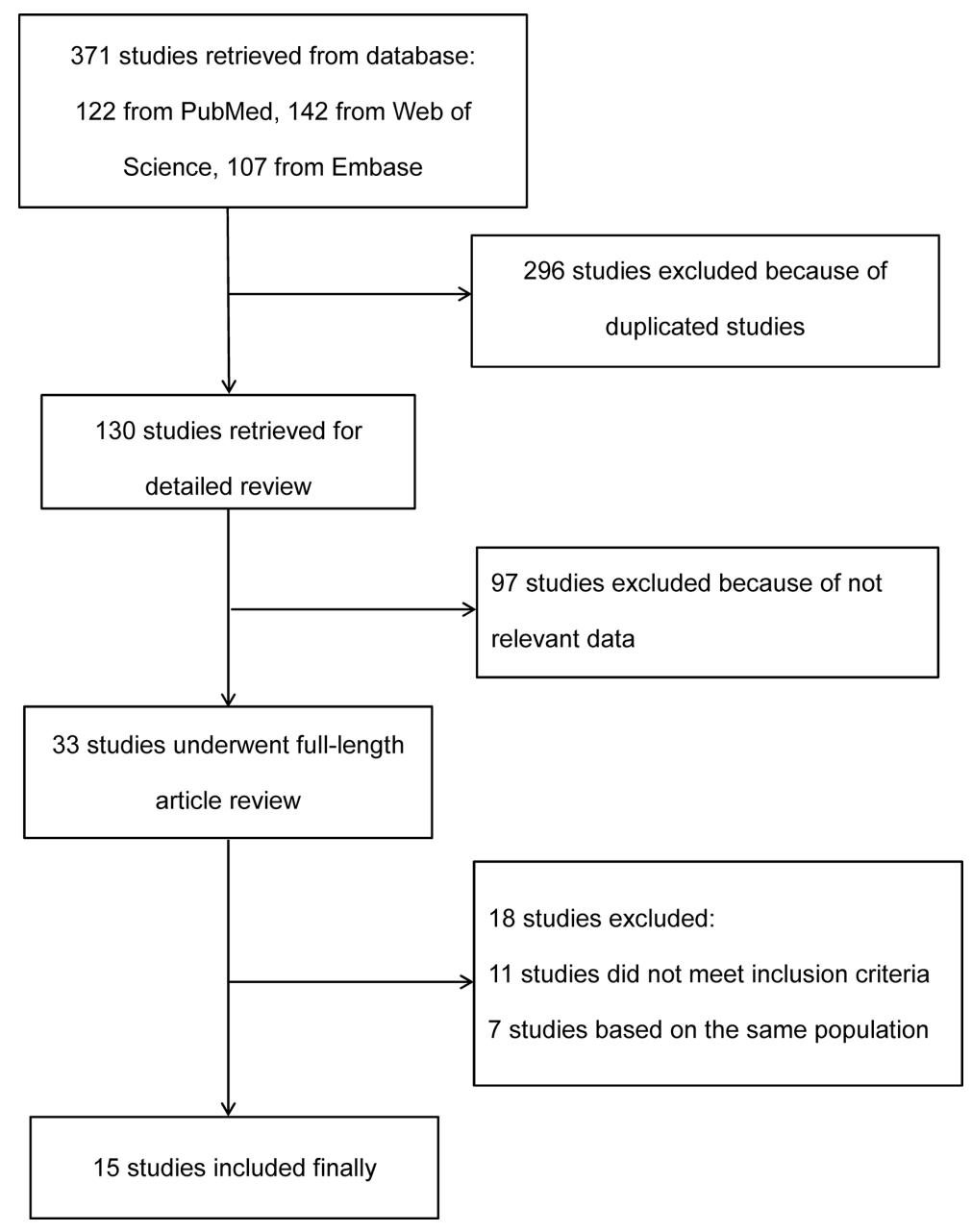

Figure 1: Flow diagram of study selection procedure. 
Table 1: Baseline characteristics of included studies in this meta-analysis

\begin{tabular}{|c|c|c|c|c|c|c|c|c|c|c|}
\hline Author & Year & $\begin{array}{l}\text { Country } \\
\text { /Area }\end{array}$ & $\begin{array}{l}\text { Study } \\
\text { design }\end{array}$ & $\begin{array}{l}\text { Number of case } \\
(M / F), \text { source }\end{array}$ & $\begin{array}{l}\text { Number of control } \\
\text { (M/F), source }\end{array}$ & $\begin{array}{l}\text { Age of } \\
\text { Case }\end{array}$ & $\begin{array}{l}\text { Age of } \\
\text { control }\end{array}$ & Adjustment & OI & $\mathbf{S Q}^{\mathrm{a}}$ \\
\hline Minami [11] & 2000 & Japan & Cohort & $\begin{array}{l}228(\mathrm{NR}), \text { medical } \\
\text { institutions in Miyagi }\end{array}$ & NR, local population & NR & NR & NR & SIR & 5 \\
\hline Elbaz [12] & 2002 & USA & Case-control & $\begin{array}{l}196(121 / 75), \text { Rochester } \\
\text { Epidemiology Project }\end{array}$ & $\begin{array}{l}196(\mathrm{NR}) \text {, local } \\
\text { population }\end{array}$ & $71(41-97)^{b}$ & NR & age, sex & OR & 7 \\
\hline Guttman [13] & 2004 & Canada & Cohort & $\begin{array}{l}15304 \text { (NR), Ontario } \\
\text { Health Insurance Plan }\end{array}$ & $\begin{array}{l}30608(\mathrm{NR}) \text {, general } \\
\text { population }\end{array}$ & NR & NR & age, sex & $\mathrm{RR}$ & 6 \\
\hline Driver [6] & 2007 & USA & Cohort & $\begin{array}{l}572 \text { (NR), Physician's } \\
\text { Health Study }\end{array}$ & $\begin{array}{l}478 \text { (NR), Physician's } \\
\text { Health Study }\end{array}$ & $\begin{array}{l}59.7(39.8 \\
-85.0)^{\mathrm{b}}\end{array}$ & $\begin{array}{l}59.8(39.8- \\
84.6)^{\mathrm{b}}\end{array}$ & age & RR & 6 \\
\hline Becker [14] & 2010 & UK & Cohort & $\begin{array}{l}2993 \text { (NR), UK-based } \\
\text { General Practice Research } \\
\text { Database }\end{array}$ & $\begin{array}{l}3003 \text { (NR), UK-based } \\
\text { General Practice } \\
\text { Research Database }\end{array}$ & NR & NR & $\begin{array}{l}\text { age, sex, general } \\
\text { practice, diagnosis date, } \\
\text { years of history }\end{array}$ & IRR & 6 \\
\hline Fois [15] & 2010 & UK & $\begin{array}{l}\text { Cohort/ } \\
\text { Case-control }\end{array}$ & $\begin{array}{l}4355(2150 / 2205), \mathrm{UK} \\
\text { National Health Service } \\
\text { hospitals }\end{array}$ & $\begin{array}{l}\text { NR, UK National Health } \\
\text { Service hospitals }\end{array}$ & NR & NR & $\begin{array}{l}\text { age }, \text { sex, calendar } \\
\text { year of first recorded } \\
\text { admission }\end{array}$ & $\mathrm{RR}$ & 7 \\
\hline Lo [16] & 2010 & USA & $\begin{array}{l}\text { Cohort/ } \\
\text { Case-control }\end{array}$ & $\begin{array}{l}692(433 / 259), \text { Kaiser } \\
\text { Permanente Northern } \\
\text { California Medical Care } \\
\text { Plan }\end{array}$ & $\begin{array}{l}761(476 / 285), \text { Kaiser } \\
\text { Permanente Northern } \\
\text { California Medical Care } \\
\text { Plan }\end{array}$ & $66.0 \pm 12.1$ & $\begin{array}{l}65.8 \\
\pm 12.1\end{array}$ & $\begin{array}{l}\text { age, sex, cigarette } \\
\text { smoking, alcohol } \\
\text { consumption, body } \\
\text { mass index }\end{array}$ & $\mathrm{RR}$ & 7 \\
\hline Kareus [17] & 2012 & USA & Cohort & $\begin{array}{l}2998(1886 / 1112), \text { Utah } \\
\text { Population Database }\end{array}$ & $\begin{array}{l}\text { NR, Utah Population } \\
\text { Database }\end{array}$ & NR & NR & age, sex, birth place & $\mathrm{RR}$ & 5 \\
\hline Rugbjerg [18] & 2012 & Denmark & Cohort & $\begin{array}{l}\text { 20343(10712/9631), } \\
\text { Danish Hospital Register }\end{array}$ & NR, general population & $72.7^{\mathrm{c}}$ & NR & $\begin{array}{l}\text { age, sex, calendar } \\
\text { period }\end{array}$ & SIR & 7 \\
\hline Wirdefeldt [19] & 2013 & Sweden & $\begin{array}{l}\text { Cohort/ } \\
\text { Case-control }\end{array}$ & $\begin{array}{l}11786(7135 / 4651) \\
\text { Swedish Patient Register }\end{array}$ & $\begin{array}{l}58930 \text { (NR), Swedish } \\
\text { Patient Register }\end{array}$ & $62.5 \pm 9.2$ & NR & sex, birth year & HR & 7 \\
\hline Ong [5] & 2014 & UK & Cohort & $\begin{array}{l}219194 \text { (NR), English } \\
\text { national Hospital Episode } \\
\text { Statistics }\end{array}$ & $\begin{array}{l}9015614(\mathrm{NR}), \text { English } \\
\text { national Hospital Episode } \\
\text { Statistics }\end{array}$ & NR & NR & $\begin{array}{l}\text { age, sex, calendar year, } \\
\text { region of residence, } \\
\text { quintile of patients }\end{array}$ & $\mathrm{RR}$ & 8 \\
\hline Lin [7] & 2015 & Taiwan & Cohort & $\begin{array}{l}62023(31486 / 30537) \text {, } \\
\text { National Health Insurance }\end{array}$ & $\begin{array}{l}124046(62972 / 61074), \\
\text { National Health } \\
\text { Insurance }\end{array}$ & NR & NR & age, sex & HR & 7 \\
\hline Freedman [20] & 2016 & USA & Case-control & NR, SEER-Medicare & NR, SEER-Medicare & NR & NR & age, sex, selection year & OR & 5 \\
\hline Peretz [21] & 2016 & Israel & Cohort & $\begin{array}{l}7125(3299 / 3826) \text {, } \\
\text { Maccabi Health Services }\end{array}$ & $\begin{array}{l}\text { NR, Maccabi Health } \\
\text { Services }\end{array}$ & $71.1 \pm 10.6$ & NR & $\begin{array}{l}\text { age, sex, chronological } \\
\text { year }\end{array}$ & SIR & 6 \\
\hline Tacik [22] & 2016 & USA & Case-control & $\begin{array}{l}971(621 / 350) \text {, Mayo } \\
\text { Clinic }\end{array}$ & $\begin{array}{l}478(215 / 263) \text {, Mayo } \\
\text { Clinic }\end{array}$ & $67(9-95)^{\mathrm{b}}$ & NR & age, sex & OR & 5 \\
\hline
\end{tabular}

Abbreviations, F:Female; HR: hazard ratio; IRR: incidence rate ratio; M:Male; NR: not report; OR: odds ratio; OI: outcome of interest; RR: relative risk; SEER: Surveillance, Epidemiology, and End Results; SIR: standardized incidence ratio; SQ: score of study quality.

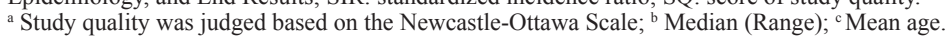

\section{Cumulative meta-analysis}

We used cumulative meta-analysis to evaluate the association between PD and lung cancer risk with relation to publication year. Our result indicated that from 2004 to present, the significant inverse relationship between PD and risk of lung cancer remained consistent (Figure S2). 


\section{DISCUSSION}

To the best of our knowledge, this meta-analysis is the first study to systematically explore the association between PD and risk of lung cancer. In this study, we included 15 studies comprising 348,780 PD patients. The pooled result indicated PD patients had a $47 \%$ decrease in risk of developing lung cancer. Furthermore, we excluded two studies which were based on Asian population and conducted further subgroup analyses in Western population. The result also showed that patients with PD were significantly associated with a decreased risk of lung cancer in Western population. The significance of the inverse association between PD and risk of lung cancer was not affected by many factors such as study design, gender and study quality. The results of sensitivity analysis and cumulative meta-analysis, and the absence of publication bias also confirmed the robustness of the relationship between them.

There were several possible explanations for the correlation of PD and the reduced risk of lung cancer. First, different essential characteristics of these two diseases may be the primary cause. PD is a neurodegenerative disorders characterized by dopaminergic neuronal death, whereas lung cancer is a disease characterized by cell unlimited growth and lack of apoptosis. Cells in PD patients may be more likely to undergo apoptosis to fight against progression of cancer [5]. Second, the treatment of PD may provide another explanation. Dopamine, which is a drug used in the therapy for PD, was reported to be an effective anti-angiogenic drug for the treatment of malignant tumors [23], thus it may decease the risk of lung cancer. Indeed, our result indicated that the significant inverse relationship between PD and risk of lung cancer could be found in after PD group, but could not be found in before PD group. On the other hand, different roles which smoking plays in PD and lung cancer may be another reason. Nicotine was reported to be as a possible neuro-protective agent in patients with PD [24]. Recent studies reported that smoking was involved in the decreased risk of PD and the increased risk of lung cancer $[9,10]$. Thus, it may also partly explain the significantly inverse association of PD and the risk of lung cancer.

Among the included studies in this study, only the studies of Minami [11] and Lin [7] were performed in Asian population. The result of study by Lin et al. showed that PD was significantly associated with an increased risk of lung cancer. This finding nearly contrary to of those in most cohort studies performed in Western populations. In other words, the results based on Western population may not be applied to Asian population. Different genetic backgrounds and habit and/or environmental factors combined may lead to the different results [7]. For instance, it was well-known that EGFR-activating mutations made patients more likely to suffer from lung cancer. The percentage of EGFR-activating mutations in lung cancer is about $50 \%$ in East Asian patients, but only $10 \%$ in White patients $[25,26]$. Until now, there was no direct evidence to prove the relationship between EGFR mutations of lung cancer and PD. However, EGFR was reported to related with PD-related genes such as PARK2 [27], whose mutation was proved to be associated with lung cancer [28]. Thus, these results may provide a possible linkage between EGFR mutations and lung cancer risk in patients with PD. On the other hand, environmental factor such as pesticide exposure was reported to be

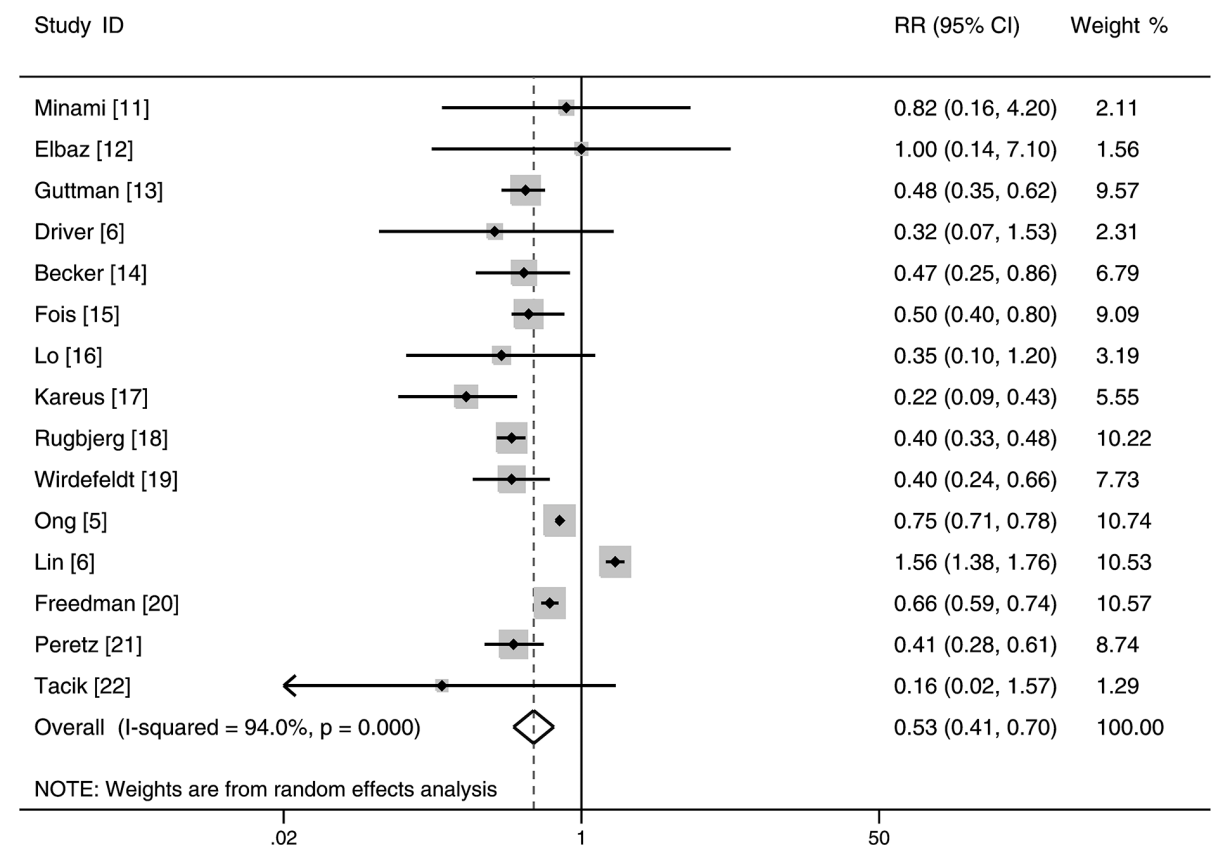

Figure 2: Forest plot of risk ratio for the association between Parkinson's disease and risk of lung cancer. 
Table 2: Subgroup analyses for association between Parkinson's disease and the risk of lung cancer in western population

\begin{tabular}{|c|c|c|c|c|c|c|}
\hline \multirow{2}{*}{ Categories } & \multirow{2}{*}{$N$} & \multirow{2}{*}{ Pooled RR } & \multirow{2}{*}{$95 \%$ CI } & \multirow{2}{*}{$P$ value } & \multicolumn{2}{|c|}{ Heterogeneity } \\
\hline & & & & & $I^{2}(\%)$ & $\mathbf{P h}$ \\
\hline Overall effect & 13 & 0.48 & $0.39-0.60$ & $<0.001$ & 84.9 & $<0.001$ \\
\hline \multicolumn{7}{|l|}{ Study design } \\
\hline Cohort & 10 & 0.45 & $0.33-0.60$ & $<0.001$ & 88.3 & $<0.001$ \\
\hline Case-control & 3 & 0.66 & $0.59-0.74$ & $<0.001$ & 0 & 0.408 \\
\hline \multicolumn{7}{|l|}{ Gender } \\
\hline Male & 5 & 0.50 & $0.33-0.77$ & $<0.001$ & 91.0 & $<0.001$ \\
\hline Female & 5 & 0.56 & $0.41-0.78$ & $<0.001$ & 68.0 & 0.010 \\
\hline \multicolumn{7}{|l|}{ Study quality } \\
\hline$>6$ & 6 & 0.50 & $0.34-0.75$ & 0.001 & 90.3 & $<0.001$ \\
\hline$\leq 6$ & 7 & 0.46 & $0.34-0.61$ & $<0.001$ & 66.1 & 0.007 \\
\hline \multicolumn{7}{|c|}{ The diagnosis time of LC } \\
\hline Before PD & 5 & 0.49 & $0.21-1.14$ & 0.100 & 89.0 & $<0.001$ \\
\hline After PD & 11 & 0.49 & $0.40-0.60$ & $<0.001$ & 86.0 & $<0.001$ \\
\hline
\end{tabular}

Abbreviations, CI: confidence interval; LC: lung cancer; N: number of studies; RR: risk ratio; PD: Parkinson's disease. Ph: $p$ value of $Q$ test for heterogeneity test.

associated with etiologies of PD [29] and the risk of lung cancer [30]. The different relationship between pesticide exposures and PD in different geographic areas may also partly explain this discrepancy $[31,32]$. This dispute needs to be solved by future studies.

There are several strengths in this study. This study is the first meta-analysis which included 15 studies comprising 348,780 patients with PD in this field. Moreover, the results of this study are still robust as performed by further subgroup analysis, sensitivity analysis and cumulative meta-analysis. Certainly, some limitations exist in this meta-analysis. First, significant heterogeneity can be found in this study. Different population groups may be the possible explanation for the heterogeneity among the included studies. Second, the included studies in this study were retrospective cohort or case-control studies. Third, we cannot perform other subgroup analyses owing to limited data in the relevant studies.

\section{CONCLUSIONS}

In summary, the result of this study indicated that patients with PD were significantly associated with a reduced risk of lung cancer in Western population. Future studies are warranted to confirm the association between them in Asian population.
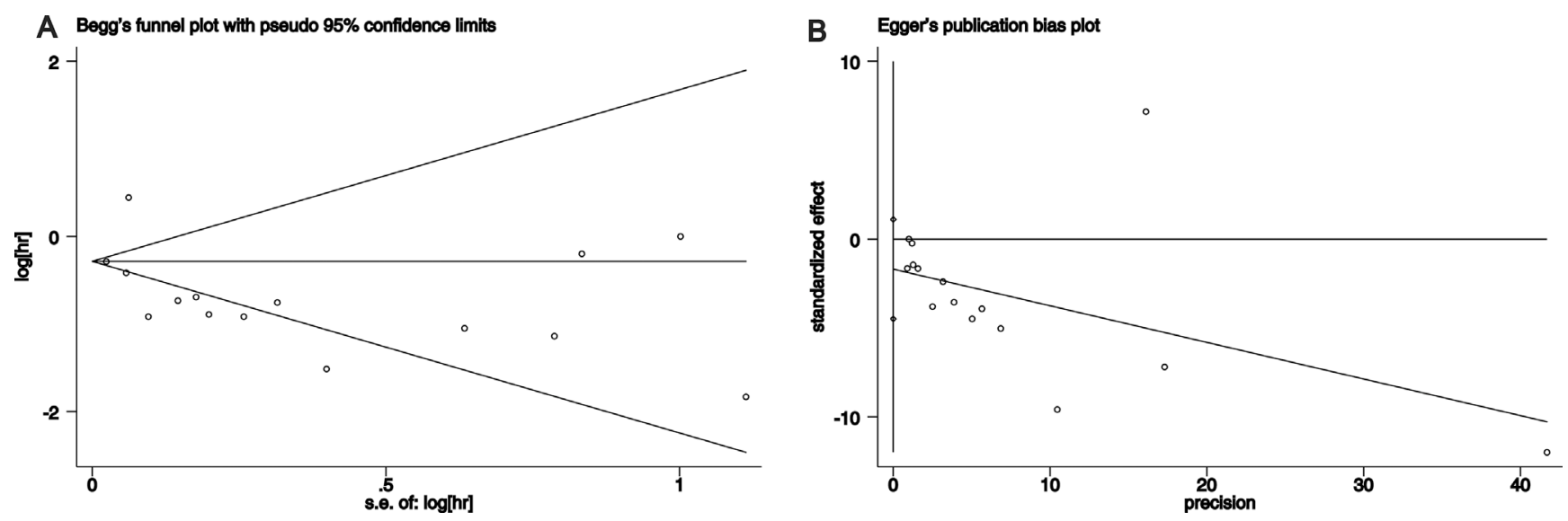

Figure 3: Test result for publication bias. (A) Begg's test $(P=0.151)$; (B) Egger's test $(P=0.214)$. 


\section{MATERIALS AND METHODS}

\section{Literature search strategy}

A comprehensive article search for relevant studies published was performed using the following online databases: PubMed, Web of Science and Embase. The main terms of "Parkinson's disease/Parkinson disease" and "Lung cancer" were used for relevant studies published up to August 31, 2016. Moreover, references of relevant reviews or included articles were also carefully reviewed to identify potential studies.

\section{Study selection and data extraction}

The eligible studies were included in our metaanalysis on the basis of the following criteria: (1) cohort and/or case-control study evaluating the relationship between PD and risk of lung cancer; (2) an estimate of association [e.g. incidence rate ratio, odds ratio, risk ratio (RR), hazard ratio or standardized incidence ratio] with measures of variation (i.e. confidence intervals, CI) was provided; (3) published study in English. When duplicated studies were based on the same population, only the most informative study was included $[7,18]$. Case reports and abstracts and from meetings were excluded.

Data of each study was extracted independently by two authors (Xin Xie and Xiaoguang Luo) according to the Preferred Reporting Items for Systematic Reviews and Meta-Analyses (PRISMA) guidelines (Table S1) [33], and any disagreements were resolved by discussion. The following data was extracted from each included study: the first author, population country, study design (cohort or case-control), publication year, patient information (i.e. sample size, source, age and sex), follow-up period and outcome of interest. The Newcastle-Ottawa scale (NOS) was used to assess the quality of included studies [34]. Study with NOS scores $>6$ (median score) was assigned as high quality study (Table S2).

\section{Statistical analysis}

The pooled RR and their $95 \%$ confidence intervals (CI) were calculated using the method of inverse variance with the random-effects model. Statistical heterogeneity was evaluated using Cochran's $Q$ test and $I^{2}$ statistics [35]. Begg's and Egger's tests were used to evaluate the effect of publication bias [36, 37]. Cumulative meta-analysis was used to assess the evolution of the combined RR with relation to the year of publication [38].

STATA software (version 12.0; Stata Corporation, College Station, TX, USA) was used to perform the data analyses in this study. It was considered statistically significant when $P$ value was less than 0.05 .

\section{ACKNOWLEDGMENTS AND FUNDING}

We thank the Department of Neurology of the First Affiliated Hospital of China Medical University for technical assistance. This research was supported by the Nature Science Foundation of China (No. 81371421).

\section{CONFLICTS OF INTEREST}

The authors declare that they have no conflicts of interest.

\section{REFERENCES}

1. de Lau LM, Breteler MM. Epidemiology of Parkinson's disease. Lancet Neurol. 2006; 5:525-535.

2. Bajaj A, Driver JA, Schernhammer ES. Parkinson's disease and cancer risk: a systematic review and meta-analysis. Cancer Causes Control. 2010; 21:697-707.

3. Catala-Lopez F, Suarez-Pinilla M, Suarez-Pinilla P, Valderas JM, Gomez-Beneyto M, Martinez S, BalanzaMartinez V, Climent J, Valencia A, McGrath J, CrespoFacorro B, Sanchez-Moreno J, Vieta E, et al. Inverse and direct cancer comorbidity in people with central nervous system disorders: a meta-analysis of cancer incidence in 577,013 participants of 50 observational studies. Psychother Psychosom. 2014; 83:89-105.

4. Liu R, Gao X, Lu Y, Chen H. Meta-analysis of the relationship between Parkinson disease and melanoma. Neurology. 2011; 76:2002-2009.

5. Ong EL, Goldacre R, Goldacre M. Differential risks of cancer types in people with Parkinson's disease: a national record-linkage study. Eur J Cancer. 2014; 50:2456-2462.

6. Driver JA, Logroscino G, Buring JE, Gaziano JM, Kurth T. A prospective cohort study of cancer incidence following the diagnosis of Parkinson's disease. Cancer Epidemiol Biomarkers Prev. 2007; 16:1260-1265.

7. Lin PY, Chang SN, Hsiao TH, Huang BT, Lin CH, Yang PC. Association Between Parkinson Disease and Risk of Cancer in Taiwan. JAMA Oncol. 2015; 1:633-640.

8. Veeriah S, Taylor BS, Meng S, Fang F, Yilmaz E, Vivanco I, Janakiraman M, Schultz N, Hanrahan AJ, Pao W, Ladanyi M, Sander C, Heguy A, et al. Somatic mutations of the Parkinson's disease-associated gene PARK2 in glioblastoma and other human malignancies. Nat Genet. 2010; 42:77-82.

9. Powers KM, Smith-Weller T, Franklin GM, Longstreth WT, Jr., Swanson PD, Checkoway H. Diabetes, smoking, and other medical conditions in relation to Parkinson's disease risk. Parkinsonism Relat Disord. 2006; 12:185-189. 
10. Copas JB, Shi JQ. Reanalysis of epidemiological evidence on lung cancer and passive smoking. BMJ. 2000; 320:417-418.

11. Minami $Y$, Yamamoto $R$, Nishikouri $M$, Fukao A, Hisamichi S. Mortality and cancer incidence in patients with Parkinson's disease. J Neurol. 2000; 247:429-434.

12. Elbaz A, Peterson BJ, Yang P, Van Gerpen JA, Bower JH, Maraganore DM, McDonnell SK, Ahlskog JE, Rocca WA. Nonfatal cancer preceding Parkinson's disease: a casecontrol study. Epidemiology. 2002; 13:157-164.

13. Guttman M, Slaughter PM, Theriault ME, DeBoer DP, Naylor CD. Parkinsonism in Ontario: comorbidity associated with hospitalization in a large cohort. Mov Disord. 2004; 19:49-53.

14. Becker C, Brobert GP, Johansson S, Jick SS, Meier CR. Cancer risk in association with Parkinson disease: a population-based study. Parkinsonism Relat Disord. 2010; 16:186-190.

15. Fois AF, Wotton CJ, Yeates D, Turner MR, Goldacre MJ. Cancer in patients with motor neuron disease, multiple sclerosis and Parkinson's disease: record linkage studies. J Neurol Neurosurg Psychiatry. 2010; 81:215-221.

16. Lo RY, Tanner CM, Van Den Eeden SK, Albers KB, Leimpeter AD, Nelson LM. Comorbid cancer in Parkinson's disease. Mov Disord. 2010; 25:1809-1817.

17. Kareus SA, Figueroa KP, Cannon-Albright LA, Pulst SM. Shared predispositions of parkinsonism and cancer: a population-based pedigree-linked study. Arch Neurol. 2012; 69:1572-1577.

18. Rugbjerg K, Friis S, Lassen CF, Ritz B, Olsen JH. Malignant melanoma, breast cancer and other cancers in patients with Parkinson's disease. Int J Cancer. 2012; 131:1904-1911.

19. Wirdefeldt K, Weibull CE, Chen H, Kamel F, Lundholm C, Fang F, Ye W. Parkinson's disease and cancer: A registerbased family study. Am J Epidemiol. 2014; 179:85-94.

20. Freedman DM, Wu J, Chen H, Engels EA, Enewold LR, Freedman ND, Goedert JJ, Kuncl RW, Gail MH, Pfeiffer RM. Associations between cancer and Parkinson's disease in U.S. elderly adults. Int J Epidemiol. 2016; [Epub ahead of print].

21. Peretz C, Gurel R, Rozani V, Gurevich T, El-Ad B, Tsamir J, Giladi N. Cancer incidence among Parkinson's disease patients in a 10-yrs time-window around disease onset: A large-scale cohort study. Parkinsonism Relat Disord. 2016; 28:68-72.

22. Tacik P, Curry S, Fujioka S, Strongosky A, Uitti RJ, van Gerpen JA, Diehl NN, Heckman MG, Wszolek ZK. Cancer in Parkinson's disease. Parkinsonism Relat Disord. 2016; [Epub ahead of print].

23. Sarkar C, Chakroborty D, Dasgupta PS, Basu S. Dopamine is a safe antiangiogenic drug which can also prevent 5-fluorouracil induced neutropenia. Int J Cancer. 2015; 137:744-749.

24. Quik M, Perez XA, Bordia T. Nicotine as a potential neuroprotective agent for Parkinson's disease. Mov Disord. 2012; 27:947-957.

25. Mok TS, Wu YL, Thongprasert S, Yang CH, Chu DT, Saijo N, Sunpaweravong P, Han B, Margono B, Ichinose Y, Nishiwaki Y, Ohe Y, Yang JJ, et al. Gefitinib or carboplatin- paclitaxel in pulmonary adenocarcinoma. N Engl J Med. 2009; 361:947-957.

26. Fukuoka M, Yano S, Giaccone G, Tamura T, Nakagawa K, Douillard JY, Nishiwaki Y, Vansteenkiste J, Kudoh S, Rischin D, Eek R, Horai T, Noda K, et al. Multi-institutional randomized phase II trial of gefitinib for previously treated patients with advanced non-small-cell lung cancer (The IDEAL 1 Trial) [corrected]. J Clin Oncol. 2003; 21:2237-2246.

27. Fallon L, Belanger CM, Corera AT, Kontogiannea M, Regan-Klapisz E, Moreau F, Voortman J, Haber M, Rouleau G, Thorarinsdottir T, Brice A, van Bergen En Henegouwen PM, Fon EA. A regulated interaction with the UIM protein Eps15 implicates parkin in EGF receptor trafficking and PIK-Akt signalling. Nat Cell Biol. 2006; 8:834-842.

28. Xiong D, Wang Y, Kupert E, Simpson C, Pinney SM, Gaba CR, Mandal D, Schwartz AG, Yang P, de Andrade M, Pikielny C, Byun J, Li Y, et al. A recurrent mutation in PARK2 is associated with familial lung cancer. Am J Hum Genet. 2015; 96:301-308.

29. Menegon A, Board PG, Blackburn AC, Mellick GD, Le Couteur DG. Parkinson's disease, pesticides, and glutathione transferase polymorphisms. Lancet. 1998; 352:1344-1346.

30. Wesseling C, Antich D, Hogstedt C, Rodriguez AC, Ahlbom A. Geographical differences of cancer incidence in Costa Rica in relation to environmental and occupational pesticide exposure. Int J Epidemiol. 1999; 28:365-374.

31. Frigerio R, Sanft KR, Grossardt BR, Peterson BJ, Elbaz A, Bower JH, Ahlskog JE, de Andrade M, Maraganore DM, Rocca WA. Chemical exposures and Parkinson's disease: a population-based case-control study. Mov Disord. 2006; 21:1688-1692.

32. Barnhill LM, Bronstein JM. Pesticides and Parkinson's disease: is it in your genes? Neurodegener Dis Manag. 2014; 4:197-200.

33. Moher D, Liberati A, Tetzlaff J, Altman DG, Group P. Preferred reporting items for systematic reviews and metaanalyses: the PRISMA statement. BMJ. 2009; 339:b2535.

34. Stang A. Critical evaluation of the Newcastle-Ottawa scale for the assessment of the quality of nonrandomized studies in meta-analyses. Eur J Epidemiol. 2010; 25:603-605.

35. Higgins JP, Thompson SG, Deeks JJ, Altman DG. Measuring inconsistency in meta-analyses. BMJ. 2003; 327:557-560.

36. Egger M, Davey Smith G, Schneider M, Minder C. Bias in meta-analysis detected by a simple, graphical test. BMJ. 1997; 315:629-634.

37. Begg CB, Mazumdar M. Operating characteristics of a rank correlation test for publication bias. Biometrics. 1994; 50:1088-1101.

38. Lau J, Schmid CH, Chalmers TC. Cumulative meta-analysis of clinical trials builds evidence for exemplary medical care. J Clin Epidemiol. 1995; 48:45-57; discussion 59-60. 